\title{
Establishing Core Competencies and a Professional Curriculum For The Care Service Department in Vocational High Schools in Taiwan
}

\author{
Nan-Chen Hsieh \\ National Taipei University of Nursing and Health Sciences \\ Shu-Fang Vivienne Wu \\ National Taipei University of Nursing and Health Sciences \\ Juin-Ming Tsai \\ National Taipei University of Nursing and Health Sciences \\ Li-Ju Lin \\ National Taipei University of Nursing and Health Sciences \\ Juo-Hsiang Sun ( $\sim$ juohsaingsun@gmail.com ) \\ National Taipei University of Nursing and Health Sciences
}

\section{Research Article}

Keywords: Vocational high school, Care service department, Core competencies, Professional curriculum, Long-term care education

Posted Date: October 27th, 2021

DOI: https://doi.org/10.21203/rs.3.rs-1009869/v1

License: (c) (i) This work is licensed under a Creative Commons Attribution 4.0 International License. Read Full License

Version of Record: A version of this preprint was published at International Journal of Environmental Research and Public Health on January 17th, 2022. See the published version at https://doi.org/10.3390/ijerph19021009. 


\section{Abstract \\ Background}

In response to the emergence of the aging society, the vocational high school education system in Taiwan has established the care service department since 2018. The purpose of this study was to develop core competencies and a professional curriculum for the care service department in vocational high schools.

\section{Methods}

This qualitative study enrolled experts and scholars in the field of long-term care as subjects. First, this study invited 20 experts and scholars to take part in a focus group to collect suggestions as the basis for the development of core competencies and a curriculum. Second, this study invited 10 experts and scholars to participate in three rounds of a Delphi survey to evaluate the planning for the development of core competencies and a curriculum that meet educational needs.

\section{Results}

In this study, we identified eight core competency constructs (interpersonal communication, care, creativity and execution, professional care, patient safety and care, resource connection and application, problem-solving and improvisation, and adherence to a professional code of conduct and ethics) and 15 indicators across two dimensions (general competencies and professional competencies) relating to the care services taught in vocational high schools. We then designed 26 professional subjects according to the core competencies.

\section{Conclusions}

In the past, the core competencies required for providing long-term care could only be cultivated in universities. In response, the Taiwanese government has promoted the cultivation of caregivers in high school, encouraging vocational high schools to establish care service departments and learning pathways to meet long-term care demands in Taiwan, overturn the stereotype that long-term care is an unspecialized profession, and enhance the willingness of young adults to work in the long-term care industry. To foster students' professional competencies, we identified the core competencies for long-term care service education and devised a professional curriculum to foster the skills and knowledge among students that are required for successfully meeting the care needs of a rapidly aging society through work in the long-term care industry after graduation.

\section{Background}

Changes in the demographic structure in Taiwan, specifically an aging population and a declining birth rate, are causing concern among policymakers. Based on the population statistics released by the National Development Council in August 2018, Taiwan is estimated to become a super-aged society by 2026, whereby the proportion of older adults aged 65 years and older is expected to increase from $14.5-20 \%$. Thereafter, the senior population is estimated to continue to grow, reaching $41.2 \%$ by 2065. [1] This growth is expected to be accompanied by an increased demand for long-term care. Therefore, long-term elderly care is a public concern that must be addressed. The 2017 Report of the Senior Citizen Condition Survey indicated that $41 \%$ of adults between 55 and 64 years of age reported having a chronic disease. This percentage increased to $65 \%$ for older adults aged 65 and older (over half the respondents). In this age group, approximately $30 \%$ of the older adults experienced difficulty in performing at least one activity of daily living (ADL) or instrumental activity of daily living (IADLs). [2] In 2019, the population requiring long-term care and assistance was 907,000 and may soon exceed one million in the near future. As the health conditions of older adults change, the demand for long-term care and caregivers will gradually increase. To solve the problem, the government in Taiwan not only begins to promote occupational education for members of society but also hopes the youth to dedicate themselves to the long-term care industry. Therefore, long-term care has been viewed as a professional subject. Specialized departments are established in universities and vocational high schools to cultivate long-term care personnel with a view to making care service personnel younger and coping with the huge needs of care in the future.

In response to the rapidly growing demand for care, the Ten-Year Plan for Long-Term Care in Taiwan was launched in 2007 to establish a long-term care service system, strengthen the infrastructure for providing long-term care services, ensure that older adults and people with physical or mental disabilities receive adequate care, and enhance people's ability to live independently with improved quality of life while maintaining their dignity and autonomy. [3] The government further announced the Long-Term Care Services Act and launched the Ten-Year Plan for Long-Term Care in Taiwan 2.0 in June 2015. Under these initiatives, the central government, local governments, and private organizations collaborate in streamlining long-term care development and building a comprehensive, community-centered, diversified, continuous, and universal long-term care service system that encompasses family care, home care, community care, and residential/institutional care, thereby fulfilling the goal of allowing older adults to age in place.

In addition to building a robust long-term care system, increasing the pool of long-term caregivers is key to establishing a long-term care service delivery system. The lack of caregivers signifies the inability to meet care demands. The Ministry of Health and Welfare generated an inventory of long-term care resources in Taiwan in 2004 and found a severe shortage of caregivers in Taiwan. [4] During this period, Taiwan had 26,942 caregivers, 30,912 less than the required number of providers. These statistics highlighted the urgent need for a long-term care service system to satisfy the demand for caregivers. In response, the Taiwanese government established the Long-Term Care System Promotion Task Force concurrently with the launch of Long-Term Care 1.0 in 2007 and listed talent cultivation as one of six major objectives. In addition, the Ministry of Education introduced a training program for long-term care professionals. The key objectives of this program are as follows: (1) to provide caregiver training; (2) to ensure satisfactory work conditions and minimize turnover; (3) to encourage professionals to pursue accreditation and enhance professional image; (4) to educate long-term caregivers through nurturing; (5) to

Page $2 / 20$ 
subsidize social work, nursing, occupational therapy, and physiotherapy departments and launch cross-disciplinary long-term care courses; (6) to assist universities and colleges in improving the quality of their long-term care departments; and (7) to continue to provide training to caregivers working in long-term care centers. [5]

Long-term caregivers are not paid due respect for the work they perform, and their professional role is seldom recognized, resulting in the continuous lack of caregivers in Taiwan. Many young adults are unwilling to become long-term caregivers because they believe that the public generally considers the industry to be socially and economically inferior to others. They believe that "care" is nonprofessional and offers no potential for future career development. Therefore, only five universities in Taiwan offered long-term care as a major in 2005, cumulatively enrolling 882 students. [6] To attract young adults to long-term care, the government began to focus on improving the professionalism and value of instruction in long-term care offered at the university level. In 2015 , the Ministry of Education established the Health Care Industry-University Cooperation Center at National Taipei University of Nursing and Health Sciences. The center serves to promote long-term caregiver cultivation and the professionalization of long-term care education. The center offers a four-module course (caregiver module, home care supervision module, care manager module, and business management module) centered on developing a career in long-term care and internship opportunities to minimize the gap between academic learning and real-world practice. As of 2019, the number of Taiwanese universities offering long-term care as a major had increased to 43 , collectively enrolling 7,383 students. [6] These results highlight the effectiveness of promoting long-term care education in universities.

However, the job of care service in Taiwan currently only has the care service personnel certificate of one single type; before 2018, whether trainees from the 90 -hour vocational training for the general public or graduates from university departments of long-term care, they could both receive the same professional certificate after taking the exam and engage themselves in care service jobs, which greatly reduced the intentions of high school graduates to enter departments of long-term care. Therefore, the government in Taiwan took the professional long-term care training curricula in Japan and Australia as reference and found that integral and professional systems of caretakers were established both in Australia and Japan with varying degrees and the differences of hours and contents have something to do with the professional certificates received. Taking Japan for example, the professionalization of longterm care in Japan is respected; long-term care personnel in Japan are categorized into four degrees, including life support adviser, care staff novice's trainee, welfare Nakura series, and care manager [7]; meanwhile, Japan National Council of Social Welfare has enacted the qualification of promotion for care service personnel and lists the categories of educational training and objectives of competence culturation. In addition, there are integral culturation curricula of gerontological care and related certificates in Australia, including four course modules: Certification III and IV in aged care, dementia care, and hospice care. The Certificate III in Individual Support has replaced the past 3 certificates: Certificate of Gerontological Care, Certificate III in Home and Community Care, Certificate III in Disability [8], and Certificate IV in Ageing Support [9]. With professional certificates and integral promotion paths, both Japan and Australia provide space for the care profession, making people with practical culturation experiences (occupational training) and formal educational training (high schools and universities, etc.) able to take different paths to acquire professional certificates of different degrees, and talents will be more willing to stay in the long-term care industry. As a result, in order to tackle the problem of lacking degree differentiation of long-term care in Taiwan, the government in Taiwan also took the culturation system in Japan and Australia as reference to differentiate the degrees of certificates.

To begin with, the Ministry of Education expanded its efforts in cultivating caregivers to high schools by introducing a pilot program for establishing care service departments in vocational high schools at the beginning of 2018. This program encourages vocational high schools in Taiwan to establish care service departments. It aims to create streamlined talent cultivation pathways from high school to university, thereby providing young adults with an attractive route for academic progression and overturning the stereotypes of long-term care. We started to try to classify long-term care, allowing high school graduates and graduates of 90-hour vocational training to participate in frontline long-term care jobs, while graduates of university departments of long-term care can further serve as home care supervisors, case managers, and care managers. Care service departments were established in seven schools in 2018,17 in 2019 , and 19 in 2020. The number of applications has risen concurrently with the urgent needs of the long-term care industry in Taiwan. Because the establishment of care service departments was in the experimental stage during the promotion of the 2018 pilot program, no standardized curriculum was available, leading to vocational high schools offering various courses that failed to encompass the professional and career requirements of long-term care. Some subjects were overly difficult and inappropriate for high school students. In response, the K-12 Education Administration, Ministry of Education, entrusted the researchers of this study to highlight the core competencies for care service workers and develop a professional curriculum for care service education in high schools. Vocational high schools aim to equip students with the knowledge required in their professional field, improve their professional knowledge, and help them form a theoretical foundation. [10] In Taiwan, we have moved into the era of 12-Year Compulsory Education since 2019; the compulsory education has extended from 9 years to 12 years with a view to elevating the quality of nationals and national competency. The 12-Year Compulsory Education includes 9 Year National Education and 3-Year High School Education. High School Education includes two categories: senior high schools and vocational high schools. Teenagers will select their path at the age of 16 according to their specialty. Generally speaking, graduates of senior high schools will enter college for further study, while graduates of vocational high schools will choose to get employed or look for further study. Therefore, vocational high schools will put more emphasis on the employability of students, helping students to acquire national certificates after graduation in order to get employed. Core competencies refer to the abilities and knowledge that should be attained before graduation to succeed in the selected profession or career. They also represent the focal abilities, knowledge, techniques, judgment, attitudes, values, and personalities required for coping with the future environment, society, and career. They include explicit knowledge, techniques, and attitudes. $[11,12,13]$ Vocational high schools provide demand-oriented education to help students secure employment or continue fostering core competencies. The findings of the Preliminary Research on Curriculum Development for Higher Vocational Education indicated that fostering high-quality workers by enhancing their core competencies is key to improving workplace competitiveness. This finding is also the basis for engaging in professional work. [14] These goals are the key objectives that are considered in the development of a professional curriculum for the care service departments of vocational high schools. Therefore, establishing core competencies associated with care services for vocational high schools can help students develop professional competencies and affects the development of professional curricula. In summary, the purpose of this study was to establish core professional competencies for the care service departments of vocational high schools and develop a corresponding professional curriculum. We determined the core competencies that vocational high school students studying care services should possess by the time of high school graduation to meet

Page $3 / 20$ 
market requirements. We also identified the professional coursework corresponding to each core competency. In this study, we collaborated with several scholars and practitioners specializing in long-term care in Taiwan to design an educational outline for teaching care services in vocational high schools in Taiwan. The outline can serve as a reference for designing professional curricula.

\section{Methods}

\section{Participants}

We adopted a qualitative research design and selected the research subjects through purposive sampling. The subjects were scholars and practitioners of long-term care in Taiwan. Research was conducted in two stages. In the first stage, we organized a focus group to collect data. We invited 10 professors and 10 practitioners to participate in a focus group interview. The inclusion criteria were as follows: (1) professors teaching long-term care in Taiwan and promoting the professionalization of long-term care education in Taiwan and (2) practitioners serving in a managerial position in the long-term care industry (care institutions or nonprofit organizations). In the second stage, we adopted the Delphi method to identify the core competencies and develop a professional curriculum that meets teaching requirements. Ten influential and pioneering experts and scholars from the field of long-term care were invited to form an expert panel. In order to make the participants better understand the goal of research and comply with research ethics, we will send descriptions of the research first via email after oral invitation, getting the informed consent of the participants in paper form. Besides, the experiment was conducted anonymously and do the coding in the format of "surname-gender-title." For example, "Wu-F-Prof." represents a female professor with the last name Wu.

\section{Material}

The purpose of this study was to develop core competencies and a professional curriculum for care services to be taught at the vocational high school level in Taiwan. The research design covered three stages namely content establishment, expert opinion collection, and expert review. The research tools included the Core Competency and Professional Syllabus Correspondence Table for Care Service Education in Vocational High Schools (Draft), Focus Group Interview Outline, and Delphi Questionnaire.

\section{Core competency and professional syllabus correspondence table for care service education in vocational high schools (draft)}

The research team reviewed relevant literature and referenced the 2019 Home Economics Syllabus for Vocational High Schools (Draft), the Test Specifications for Care Services of the Council of Labor Affairs, Executive Yuan, the professional curricula used in long-term care undergraduate programs, and the professional curricula used in the pilot care service departments of vocational high schools to formulate the Core Competency and Professional Syllabus Correspondence Table for Care Service Education in Vocational High Schools (Draft). The core competencies were based on the fundamental belief of the Curriculum Guidelines of the 12-Year Basic Education that education is based on the spirit of holistic education and cultivating practical professionals to meet industry demands. Therefore, core competencies can be divided into general and professional competencies. General competencies are based on the fundamental principles of "taking initiative, engaging in interaction, and seeking the common good" stipulated in the Curriculum Guidelines of the 12-Year Basic Education. Professional competencies are based on the skill indices and professional competencies required for development at the high school level stipulated in the "Test Specifications for Care Services." The two dimensions of competencies comprised a total of seven constructs and 13 indicators, of which general competencies accounted for two constructs and four indicators and professional competencies accounted for five constructs and nine indicators. Subsequently, a professional curriculum comprising 25 subjects was developed based on the core competencies selected in this study. (Please see attachment 1)

\section{Focus group interview outline}

The objective of the proposed draft was to solicit a wide range of expert opinions in long-term care. Therefore, a five-item focus group interview outline was created. The items were the following: (1) What are your opinions on the two general competencies and five professional competencies selected for this draft? (2) What are your opinions on the three subjects (Introduction to Long-Term Care, Basic Care Practices and Experiments, and Practical Training on Basic Care) designed for the professional curriculum based on the Test Specifications for Long-Term Caregivers in Taiwan? (3) What are your opinions on the four subjects centered on the general competency indicators? (4) What are your opinions on the 25 professional subjects centered on the professional competency indicators selected for the draft? and (5) What are your recommendations for schools aspiring to develop unique teaching plans for long-term care?

\section{Delphi questionnaire}

The initial draft was modified based on the content analysis results in Stage 1 and the focus group interview in Stage 2. The first Delphi questionnaire was then compiled. To help the expert panel better understand the content of the questionnaire and provide answers, the questionnaire was accompanied by a research explanation letter and a set of instructions.

The purpose of the research explanation letter was to communicate relevant matters concerning the research with the experts. The research explanation letter for the first questionnaire included detailed research objectives, the implementation method and procedures, the expected schedule, and a glossary of terms. The research explanation letter for the second questionnaire and later questionnaires included the data processing method and results of the previous iteration, a compilation of expert opinions, and a list of amendments made in the current version of the questionnaire. The instructions presented the structure of the questionnaire and instructions on how to answer the questionnaire. In the second questionnaire and later versions, a statistical analysis of the items in the previous iterations and a compilation of expert opinions were provided to serve as references when reconsidering the questionnaire items. The experts were asked to elaborate if their opinions differed from the overall consensus. 
The questionnaire content was presented in three parts, specifically, a core competency survey, a professional curriculum survey, and other suggestions. The core competency survey comprised 21 items in two constructs. The questionnaire was scored on a 5-point scale, where 1 indicated "nonapplicable" and 5 indicated "very applicable." The professional curriculum survey comprised 26 items in two constructs. This questionnaire was also scored on a 5-point scale, where 1 indicated "nonapplicable" and 5 indicated "very applicable." The other suggestions section comprised an open-ended question in response to which experts could provide their suggestions regarding the current questionnaire. Thereafter, the researchers systematically analyzed the outcomes of the previous surveys and questionnaire content and considered the significant evaluation results and expert opinions for each item to produce subsequent iterations of the questionnaire.

\section{Procedure}

The K-12 Education Administration, Ministry of Education, entrusted the current research team with identifying the core professional competencies and formulating a professional curriculum for the care service departments in vocational high schools in Taiwan. This study was conducted in three stages. The first stage comprised a literature review and content analysis. The first stage comprised a literature review and content analysis, which took half a year. During the conceptualization of the proposed draft, we assembled a curriculum promotion task force comprising eight professors specializing in long-term care (including members involved in designing high school syllabuses for the Ministry of Education) to identify the core competencies and draft a professional curriculum. To collect more opinions, we organized two academic and industry focus groups during the second stage. The opinions of 20 experts and scholars of long-term care were collected. Each focus group continued until data saturation, lasting approximately 2 hours. Two focus groups are held in this research eventually. During this phrase, it took 2 months to invite experts, organize focus groups, and analyze the data. In the third stage, the research results obtained in the first and second stages were consolidated and used to modify the draft. Thereafter, the modified draft was submitted for expert review. The Delphi survey method was adopted in the third stage and comprised three rounds of questionnaire surveys. The survey period was 3 months and involved a panel of 10 experts. The overall questionnaire recovery rate was $100 \%$. Research was conducted as a team. The main research tasks included collecting and amending the research data, inviting and confirming the research subjects, and collecting and analyzing the research data. After each round of data collection and analysis, the research team encoded the data for data analysis and triangulation. This approach facilitated the research team attaining consensus and ensured reliability and validity.

The research can be exempt from the ethical review of human research according to the regulations of the Review Committee since the case does not take noadults, inmates, aboriginals, pregnant women, physically or mentally challenged, psychosis patients, or people under unreasonable threat or unable to decide based on free will as objects of research, conduct anonymous non-intrusive research in public places, the information gathered is unrecognizable as specific individual, and thus exempt from the ethical review of the Review Committee (Ministry of Health and Welfare, 2012). The research also abides by the regulations of journals to apply for the ethical review of the Review Committee (Research Ethics Committee" (REC) of "National Taiwan University" (NTU), Case Number: 202011ES013). In this study, the informed consent was obtained from all the participants on the basis of the aforementioned article, as well as the fact that the research is commissioned by the public sectors for professional institutes to conduct national policy related research, the objects of research are found for the purpose of sharing academic professional knowledge and providing recommendations, which do not belong to the domain governed by the Review Committee and thus can be exempt from the ethical review. In order to make the participants better understand the goal of research and comply with research ethics, we will send descriptions of the research first via email after oral invitation, getting the informed consent of the participants in paper form.

\section{Data analysis}

A hierarchical stepwise induction approach was adopted for the focus groups. The researchers first highlighted the meaningful codes in the interview transcripts. Related, similar, or identical codes were grouped into units, and the units were consolidated into subthemes (Table 1). Finally, the researchers reviewed the themes to ensure that they conformed with the research objectives. To ensure objectivity, the data were cross-coded and cross-inspected within the research team. Subjective biases were avoided by engaging in collaborative discussions and interpretive dialogues or submitting the transcripts for peer review and discussion.

Table 1

Example of a data analysis table.

\begin{tabular}{|c|c|c|c|}
\hline Theme & Subtheme & Unit & Code \\
\hline \multirow[t]{3}{*}{$\begin{array}{l}\text { Future } \\
\text { development of } \\
\text { care service } \\
\text { departments in } \\
\text { vocational high } \\
\text { schools }\end{array}$} & \multirow[t]{3}{*}{$\begin{array}{l}\text { A comprehensive curriculum } \\
\text { should consider optimal } \\
\text { health, suboptimal health, } \\
\text { and care requirement } \\
\text { subjects }\end{array}$} & $\begin{array}{l}\text { Course arrangement should } \\
\text { be based on optimal health } \\
\text { and suboptimal health } \\
\text { courses while addressing } \\
\text { disability }\end{array}$ & $\begin{array}{l}\text { I stress that schools must play on their strengths, and course } \\
\text { arrangement should be based on optimal health and suboptimal } \\
\text { health courses while disability should be included in the other } \\
\text { health courses. (Huang-F-P) }\end{array}$ \\
\hline & & $\begin{array}{l}\text { Disability prevention courses, } \\
\text { such as optimal health and } \\
\text { suboptimal health, should be } \\
\text { included }\end{array}$ & $\begin{array}{l}\text { Development can be viewed in two dimensions. First, we should } \\
\text { not focus on care. Second, we should include optimal health and } \\
\text { suboptimal health groups and discuss "disability prevention" in } \\
\text { our discussions. (Chen-M-N) }\end{array}$ \\
\hline & & $\begin{array}{l}\text { Courses should cover healthy } \\
\text { living and disease care }\end{array}$ & $\begin{array}{l}\text { Care and healthy living were mentioned. I believe that these } \\
\text { concepts should be included. Older adults must first lead a } \\
\text { healthy lifestyle. They only require care when they are ill. As } \\
\text { mentioned, these concepts must be emphasized. (Yang-M-P) }\end{array}$ \\
\hline
\end{tabular}

The survey comprised two parts, a qualitative analysis and a quantitative analysis. In the qualitative analysis, the researchers consolidated similar or identical opinions provided by the experts. The research team then discussed the opinions and determined whether adjustments were required. In the quantitative 
analysis, the responses for the three rounds of questionnaire surveys were presented as mean values and modes. The expert opinions and mean, standard deviation, and quartile deviation values were adopted as a reference for consistency and consensus. [15] To ensure the accuracy of the research results, the researchers adopted mean values, modes, quartile deviation values, and standard deviations values as the determination criteria. The reference criteria were as follows: (1) a mean value of $\geq 3.5$ or a mode value of $\geq 3$ denoted a high level of importance, (2) a quartile deviation value of $<1$ or a standard deviation value of $\leq 1$ denoted that expert consensus had been reached, and (3) a mean value of $<3.5$ or a mode value of $\leq 3$ and a quartile deviation value of $<1$ denoted the deletion criteria.

\section{Results}

\section{Analysis of the focus group interview}

In this study, we organized focus groups to determine the suitability of the research content and identify the key factors associated with the core competencies and professional curriculum of care services in high schools. The researchers modified the Core Competency and Professional Syllabus Correspondence Table for Care Service Education in Vocational High Schools based on the focus group results. Thereafter, the Delphi questionnaire was administered. Based on the focus group outcomes, first of all, we added one construct to general competencies and modified "communication and care" to "interpersonal communication" and "care." Originally, they were "Communication and Caring Competency", along with "Creativity and Planning Capability", but the members of the focus group consider that care, for caretakers, is an important capability; therefore, it is especially listed as an independent core competence and we hope that the capability can reach the indicator of "Creating shared value"; by means of care, the mutual goal of common good between caretakers and care recipients. Therefore, the general competency dimension comprised three constructs (i.e., interpersonal communication, care, and creativity and execution) and four indicators. The five constructs in professional competencies were maintained. However, we considered that students may not yet have developed leadership skills in high school and replaced "leadership" with "problem-solving and improvisation." Besides, developing two indicators, the ability to analyze problems in case studies and the ability to solve problems in case studies, in the dimension of problem-solving and improvisation, with a view to cultivating among students professional capabilities to analyze and solve the care problems of cases. In the part of "The Capability of Resource Integration", we originally hope students can reach the indicator of "Getting to Know Related Laws and Regulations of Care Service"; however, after the assessment of committee members, they considered that the laws and regulations during high school are too difficult; moreover, high school graduates are usually frontline practitioners, so it was advised that the two indicators should be changed into "Being acquainted and connected with care resources" and "Encouraging health promotion activities", hoping to connect resources and put it into practice. A total of 11 indicators were identified for the five constructs. The focus group identified 14 indicators across eight constructs in the general and professional competencies dimensions. (Change the comparison Table2) 
Table 2

The Revision and Reference Table of Core Competence Focus Group

\begin{tabular}{|c|c|c|}
\hline The Original Version (The Draft) & $\begin{array}{l}\text { The Revised Version } \\
\text { (Suggested by Focus Groups) }\end{array}$ & Remark \\
\hline General Competency & General Competency & \\
\hline 1. Comunication and Caring Competency & 1. Interpersonal communication & \multirow{4}{*}{$\begin{array}{l}\text { Revising the content and focusing on the culturation of } \\
\text { capability to interact interpersonally. }\end{array}$} \\
\hline $\begin{array}{l}1.1 \text { Interpersonal Relations and Communication } \\
\text { Skills }\end{array}$ & 1. 1 Interpersonal relationship & \\
\hline $\begin{array}{l}\text { 1.2 Family Support: Needs and Assistance of } \\
\text { Family Care }\end{array}$ & 1. 2 Interactive literacy & \\
\hline \multicolumn{2}{|l|}{ 1.3 Hospice Care and getting to know hospice } & \\
\hline & 2.Care & \multirow[t]{2}{*}{ Appending and listed as the sole important capability. } \\
\hline & 2.1 Creating shared value & \\
\hline 2. Creativity and Planning Capability & 3. Creativity and execution & \multirow{2}{*}{$\begin{array}{l}\text { Revising the content and the objects are not limited to the } \\
\text { elderly. }\end{array}$} \\
\hline $\begin{array}{l}\text { 2.1 The Planning of Gerontological Activity } \\
\text { Programs }\end{array}$ & $\begin{array}{l}3.1 \text { Proactive creativity and program } \\
\text { execution }\end{array}$ & \\
\hline Professional Competency & Professional Competency & \\
\hline
\end{tabular}

\section{Professional care}

\section{Professional care}

1.1 Basic Caring skills: Caring of the Body and Life; Dealing with Household Chores

1.2 Care in Context: Care Training of Different Categories

1.1 Basic caring skills

1.3 General Clinical Nursing Techniques

1.2 Practical caring skills in real situations

1.3 Accuracy of case assessment ability

Revision. It should be adapted into the capability to assess.

\section{Patient safety and care}

\section{Patient safety and care}

2.1 Dealing with accidents and emergencies

2.2 Care and life safety

2.2 Care and life safety

3. Adherence to a professional code of conduct and ethics

3. Adherence to a professional code of conduct and ethics

3.1 Abiding by Work Ethics

3.1 Abiding by Work Ethics

3.2 Understanding the regulations Append related to caring services

\section{The Capability of Leadership}

Delete

4.1 Developing Activities of Health Promotion

4.2 Promoting Active Aging in Communities

4. Problem-solving and improvisation

Append

4.1 Ability to analyze problems in case studies

4.2 Ability to solve problems in case studies

\section{The Capability of Resource Integration}

\section{Resource connection and} application

Revision. Turning resource integration into resource linkage.

5.1 Being acquainted and connected with care resources

5.1 Getting to Know Related Laws and Regulation of Care Service

5.2 Encouraging health promotion activities

For the professional curriculum, three compulsory courses were identified for the caregiver examination, namely "Introduction to Long-Term Care," "Basic Care Practices and Experiments," and "Practical Training in Basic Care." Other courses included institutional care, community care, and home care courses to foster situational care competency among students. Based on the revised capability, we deleted two curricular: "Hospice Care" and "An Introduction to Family". 
Palliative care is an advanced course unsuitable for high school students. Therefore, this course was omitted. A "case management course" was added to coincide with the addition of the new core competency, "problem-solving and improvisation." Besides, adding the "Introduction to Case Management" course, integrating "The Practice of Health Promotion" and "Community Health Construction $\nabla$ 邓" as "Practical Project ( $($ ) ( $($ )", appending "The Policies and Laws of Long-Term Care" and "Community Health Building", and as for the rest, some are doing adjustments in the names of the courses. For detailed revised references, please see Table 3. Based on the expert recommendations, a total of 26 professional courses were identified in the focus group. 
Table 3

The Revision Reference Table of Professional Curriculum after Focus Group

\begin{tabular}{|c|c|c|c|}
\hline & & $\begin{array}{l}\text { Professional subjects } \\
\text { (after revision) }\end{array}$ & Situations of Revision \\
\hline \multirow[t]{8}{*}{$\begin{array}{l}\text { General } \\
\text { Competency }\end{array}$} & $\begin{array}{l}\text { 1. Interpersonal } \\
\text { communication }\end{array}$ & & \multirow[t]{3}{*}{$\begin{array}{l}\text { Deleting "Hospice Care" and "An Introduction to Family" Curricula Based on } \\
\text { Revised Capability }\end{array}$} \\
\hline & $\begin{array}{l}1.1 \text { Interpersonal } \\
\text { relationship }\end{array}$ & \multirow{2}{*}{$\begin{array}{l}\text { Interpersonal } \\
\text { relationships and } \\
\text { communication }\end{array}$} & \\
\hline & 1.2 Interactive literacy & & \\
\hline & \multicolumn{2}{|l|}{ 2. Care } & \multirow[t]{2}{*}{ Appending } \\
\hline & 2.1 Creating shared value & $\begin{array}{l}\text { Introduction to human } \\
\text { development }\end{array}$ & \\
\hline & \multicolumn{2}{|l|}{ 3. Creativity and execution } & \multirow{3}{*}{$\begin{array}{l}\text { Not focusing on the elderly; therefore, deleting "The Design of Gerontological } \\
\text { Activity" and appending the curriculum of "Activity Design and Conduct". }\end{array}$} \\
\hline & \multirow[t]{2}{*}{$\begin{array}{l}3.1 \text { Proactive creativity } \\
\text { and program execution }\end{array}$} & $\begin{array}{l}\text { Activity design and } \\
\text { conduct }\end{array}$ & \\
\hline & & $\begin{array}{l}\text { Design and } \\
\text { applications for } \\
\text { assistive program }\end{array}$ & \\
\hline \multirow{18}{*}{$\begin{array}{l}\text { Professional } \\
\text { Competency }\end{array}$} & \multicolumn{3}{|l|}{ 1. Professional care } \\
\hline & \multirow[t]{3}{*}{ 1.1 Basic caring skills } & $\begin{array}{l}\text { Introduction to long- } \\
\text { term care (I)(II) }\end{array}$ & \multirow[t]{3}{*}{ The three required courses for the exam of certificates need to be emphasized. } \\
\hline & & $\begin{array}{l}\text { Practical basic care } \\
\text { and experimental (I) } \\
\text { (II) }\end{array}$ & \\
\hline & & $\begin{array}{l}\text { Practicum for } \\
\text { fundamental care (I) } \\
\text { (II) }\end{array}$ & \\
\hline & \multirow[t]{3}{*}{$\begin{array}{l}1.2 \text { Practical caring skills } \\
\text { in real situations }\end{array}$} & $\begin{array}{l}\text { Long-term care } \\
\text { facilities and practice } \\
\text { techniques }\end{array}$ & \multirow[t]{3}{*}{$\begin{array}{l}\text { Designing courses according to different care fields, including institutional, } \\
\text { community, and home-care. }\end{array}$} \\
\hline & & $\begin{array}{l}\text { Practicum for } \\
\text { community care }\end{array}$ & \\
\hline & & $\begin{array}{l}\text { Practicum for home } \\
\text { care }(I)(I I)\end{array}$ & \\
\hline & \multirow[t]{2}{*}{$\begin{array}{l}1.3 \text { Accuracy of case } \\
\text { assessment ability }\end{array}$} & $\begin{array}{l}\text { Structure and function } \\
\text { of human body (I)(II) }\end{array}$ & \\
\hline & & $\begin{array}{l}\text { Physical examination } \\
\text { and assessment (I)(II) }\end{array}$ & \\
\hline & \multicolumn{3}{|l|}{ 2. Patient safety and care } \\
\hline & \multirow[t]{2}{*}{$\begin{array}{l}2.1 \text { Dealing with accidents } \\
\text { and emergencies }\end{array}$} & $\begin{array}{l}\text { Dealing with } \\
\text { accidents and } \\
\text { emergencies }\end{array}$ & $\begin{array}{l}\text { Deleting the original course: "Occupational Safety and Harm Prevention" and } \\
\text { appending the two courses }\end{array}$ \\
\hline & & $\begin{array}{l}\text { Home security and } \\
\text { accident prevention }\end{array}$ & \\
\hline & \multirow[t]{5}{*}{ 2.2 Care and life safety } & $\begin{array}{l}\text { Introduction to } \\
\text { nutrition (I)(II) }\end{array}$ & \\
\hline & & $\begin{array}{l}\text { Disease prevention } \\
\text { and chronic care }\end{array}$ & \\
\hline & & $\begin{array}{l}\text { Introduction to drug } \\
\text { therapy and } \\
\text { medication safety }\end{array}$ & \\
\hline & & $\begin{array}{l}\text { Assistive technology } \\
\text { device and health care }\end{array}$ & \\
\hline & & $\begin{array}{l}\text { Practicum for } \\
\text { assistive technology } \\
\text { device }\end{array}$ & \\
\hline & $\begin{array}{l}\text { 3. Adherence to a } \\
\text { professional code of } \\
\text { conduct and ethics }\end{array}$ & & \\
\hline
\end{tabular}




\begin{tabular}{|c|c|c|}
\hline & $\begin{array}{l}\text { Professional subjects } \\
\text { (after revision) }\end{array}$ & Situations of Revision \\
\hline $\begin{array}{l}\text { 3.1 Compliance with the } \\
\text { code of ethics and } \\
\text { regulations }\end{array}$ & $\begin{array}{l}\text { Ethics in long-term } \\
\text { care }\end{array}$ & \multirow[t]{2}{*}{ Appending the course: "Long-Term Care Policies and Laws" } \\
\hline $\begin{array}{l}3.2 \text { Understanding the } \\
\text { regulations related to } \\
\text { caring services }\end{array}$ & $\begin{array}{l}\text { Long-term care policy } \\
\text { and regulation }\end{array}$ & \\
\hline \multicolumn{3}{|l|}{$\begin{array}{l}\text { 4. Problem-solving and } \\
\text { improvisation }\end{array}$} \\
\hline $\begin{array}{l}\text { 4.1 Ability to analyze } \\
\text { problems in case studies }\end{array}$ & $\begin{array}{l}\text { Introduction to case } \\
\text { management }\end{array}$ & \multirow{2}{*}{ 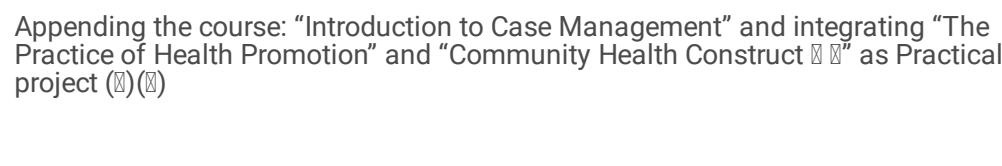 } \\
\hline $\begin{array}{l}4.2 \text { Ability to solve } \\
\text { problems in case studies }\end{array}$ & Practical project (I)(II) & \\
\hline \multicolumn{3}{|l|}{$\begin{array}{l}\text { 5. Resource connection } \\
\text { and application }\end{array}$} \\
\hline $\begin{array}{l}5.1 \text { Being acquainted and } \\
\text { connected with care } \\
\text { resources }\end{array}$ & $\begin{array}{l}\text { Introduction to social } \\
\text { welfare }\end{array}$ & \multirow[t]{3}{*}{$\begin{array}{l}\text { Changing "An Introduction to Long-Term Care Laws and Regulations" into } \\
\text { "Introduction to Social Welfare" }\end{array}$} \\
\hline \multirow{2}{*}{$\begin{array}{l}5.2 \text { Encouraging health } \\
\text { promotion activities }\end{array}$} & $\begin{array}{l}\text { Health promotion } \\
\text { practicum }\end{array}$ & \\
\hline & $\begin{array}{l}\text { Community health } \\
\text { building }\end{array}$ & \\
\hline
\end{tabular}

\section{Establishment and analysis of the core competencies for care service education in vocational high schools}

A total of 14 indicators across eight constructs in two core competency dimensions were preliminarily identified based on the focus group outcomes. The core competencies were included in the first round of the Delphi questionnaire survey. After the questionnaires were recovered, the opinions provided by the expert panel were collected and analyzed. The original list of 14 indicators across eight constructs in two core competency dimensions was retained. However, the descriptions of "creativity and execution" and "resource connection and application" were modified. Committee members considered that students at the age of high school are mainly required to cultivate the competence of creativity activation and program execution; therefore, the original "spontaneous creation, program planning and execution" has been simplified as "spontaneous creation and program execution". In addition, as for the capability to connect resources and put into application, we added "to assist" to "to advertise health promotion activities"; for the main part, it is taken into consideration that students are not yet able to lead health promotion activities independently; as a result, we hope that we can cultivate the capability to assist and promote activities of health promotion first. Fourteen indicators across eight constructs in two core competency dimensions were included in the second round of the Delphi questionnaire survey. The opinions of the expert panel were once again collected and analyzed. The eight constructs and two dimensions were retained. However, one indicator was added, for a total of 15 indicators, and the description of one indicator was modified. One indicator was added to the "problem-solving and improvisation" construct, and the original description was modified. We added "The Capability to Perceive the Problems of Cases" and turned the two words in "The Capability to Solve Problems" into "The Executive Capability to Solve Problems of Cases", hoping to cultivate among students capabilities to discover problems and solve problems. The revised list of core competencies was carried over to the third round of the Delphi questionnaire survey. The experts provided no further opinions in the third round, and the statistical data met all of the pre-established criteria, suggesting that expert consensus was achieved. In this round, all the written expert opinions were acknowledged and corrected. The modifications made in the three rounds of the Delphi questionnaire survey are noted in Table 4. 
Table 4

Questionnaire amendments of the core competencies in the three-round Delphi questionnaire survey $(n=$

\begin{tabular}{|c|c|c|c|c|c|c|c|c|c|c|c|c|}
\hline \multirow{2}{*}{$\begin{array}{l}\text { Indicator } \\
\text { dimension }\end{array}$} & \multirow{2}{*}{$\begin{array}{l}\text { Indicator } \\
\text { construct }\end{array}$} & \multicolumn{5}{|c|}{ Amendments in Round 1} & \multicolumn{5}{|c|}{ Amendments in Round 2} & \multirow{2}{*}{$\begin{array}{l}\text { Amen } \\
\text { Origin } \\
\text { items }\end{array}$} \\
\hline & & $\begin{array}{l}\text { Original } \\
\text { items }\end{array}$ & Retained & Amended & Deleted & Added & $\begin{array}{l}\text { Original } \\
\text { items }\end{array}$ & Retained & Amended & Deleted & Added & \\
\hline \multirow[t]{3}{*}{$\begin{array}{l}\text { General } \\
\text { competencies }\end{array}$} & $\begin{array}{l}\text { Interpersonal } \\
\text { communication }\end{array}$ & 2 & 2 & 0 & 0 & 0 & 2 & 2 & 0 & 0 & 0 & 2 \\
\hline & Care & 1 & 1 & 0 & 0 & 0 & 1 & 1 & 0 & 0 & 0 & 1 \\
\hline & $\begin{array}{l}\text { Creativity and } \\
\text { execution }\end{array}$ & 1 & 1 & 1 & 0 & 0 & 1 & 1 & 0 & 0 & 0 & 1 \\
\hline \multirow[t]{5}{*}{$\begin{array}{l}\text { Professional } \\
\text { competencies }\end{array}$} & $\begin{array}{l}\text { Professional } \\
\text { care }\end{array}$ & 3 & 3 & 0 & 0 & 0 & 3 & 3 & 0 & 0 & 0 & 3 \\
\hline & $\begin{array}{l}\text { Patient safety } \\
\text { and care }\end{array}$ & 2 & 2 & 0 & 0 & 0 & 2 & 2 & 0 & 0 & 0 & 2 \\
\hline & $\begin{array}{l}\text { Resource } \\
\text { connection and } \\
\text { application }\end{array}$ & 2 & 2 & 1 & 0 & 0 & 2 & 2 & 0 & 0 & 0 & 2 \\
\hline & $\begin{array}{l}\text { Problem- } \\
\text { solving and } \\
\text { improvisation }\end{array}$ & 1 & 1 & 0 & 0 & 0 & 1 & 1 & 1 & 0 & 1 & 2 \\
\hline & $\begin{array}{l}\text { Adherence to a } \\
\text { professional } \\
\text { code of } \\
\text { conduct and } \\
\text { ethics }\end{array}$ & 2 & 2 & 0 & 0 & 0 & 2 & 2 & 0 & 0 & 0 & 2 \\
\hline
\end{tabular}

The opinions provided by the expert panel in the three-round questionnaire survey concerning the overall importance and consistency of the core competencies of care services for education in vocational high schools are presented in Table 5 . In the "general competencies" dimension, (1) the mean values for the "interpersonal communication" construct and relevant indicators ranged between 4.8 and 4.9. The mode value was 5 , quartile deviation value was 0 , and standard deviation value was less than 1. (2) The mean values for the "care" construct and relevant indicators ranged between 4.7 and 4.8 . The mode value was 5 , quartile deviation value was 0 , and standard deviation value was less than 1 . (3) The mean value for the "creativity and execution" construct and relevant indicators was 4 . The mode value was 5 , quartile deviation value was 0 , and standard deviation value was less than 1 . These results indicated that all the constructs and indicators in the general competencies were important and that the experts had a strong consensus regarding consistency. 
Overall importance and consistency of the core competencies for care service education in vocational high schools $(n=10)$.

\begin{tabular}{|c|c|c|c|c|c|}
\hline \multirow[t]{2}{*}{ Indicator dimension } & \multirow[t]{2}{*}{ Indicator construct and indicators } & \multicolumn{2}{|c|}{ Importance } & \multicolumn{2}{|l|}{ Consistency } \\
\hline & & Mean & Mode & Quartile Deviation & Standard deviation \\
\hline \multirow[t]{7}{*}{ General competencies } & 1. Interpersonal communication & 4.9 & 5 & 0 & 0.3 \\
\hline & 1. 1 Interpersonal relationship & 4.9 & 5 & 0 & 0.3 \\
\hline & 1. 2 Interactive literacy & 4.8 & 5 & 0 & 0.4 \\
\hline & 2. Care & 4.7 & 5 & 0 & 0.6 \\
\hline & 2.1 Creating shared value & 4.8 & 5 & 0 & 0.6 \\
\hline & 3. Creativity and execution & 4.0 & 4 & 0 & 0.4 \\
\hline & 3.1 Proactive creativity and program execution & 4.0 & 4 & 0 & 0.4 \\
\hline \multirow[t]{16}{*}{ Professional competencies } & 4. Professional care & 4.9 & 5 & 0 & 0.3 \\
\hline & 4.1 Basic caring skills & 5.0 & 5 & 0 & 0 \\
\hline & 4.2 Practical caring skills in real situations & 4.5 & 5 & 0 & 0.7 \\
\hline & 4.3 Accuracy of case assessment ability & 4.5 & 5 & 0.75 & 0.9 \\
\hline & 5. Patient safety and care & 5.0 & 5 & 0 & 0 \\
\hline & 5.1 Dealing with accidents and emergencies & 5.0 & 5 & 0 & 0 \\
\hline & 5.2 Care and life safety & 5.0 & 5 & 0 & 0 \\
\hline & 6. Resource connection and application & 4.6 & 5 & 0.75 & 0.7 \\
\hline & 6.1 Being acquainted and connected with care resources & 4.6 & 5 & 0.75 & 0.7 \\
\hline & 6.2 Encouraging health promotion activities & 4.4 & 5 & 1 & 0.8 \\
\hline & 7. Problem-solving and improvisation & 4.9 & 5 & 0 & 0.3 \\
\hline & 7.1 Ability to analyze problems in case studies & 4.9 & 5 & 0 & 0.3 \\
\hline & 7.2 Ability to solve problems in case studies & 4.9 & 5 & 0 & 0.3 \\
\hline & 8. Adherence to a professional code of conduct and ethics & 5.0 & 5 & 0 & 0 \\
\hline & 8.1 Compliance with the code of ethics and regulations & 5.0 & 5 & 0 & 0 \\
\hline & 8.2 Understanding the regulations related to caring services & 4.9 & 5 & 0 & 0.3 \\
\hline
\end{tabular}

In the "professional competencies" dimension, (1) the mean value for the "patient safety and care" construct and relevant indicators was 5. The mode value was 5 , quartile deviation value was 0 , and standard deviation value was less than 1 . (2) The mean value for the "problem-solving and improvisation" construct and relevant indicators was 4.9. The mode value was 5 , quartile deviation value was 0 , and standard deviation value was less than 1 . (3) The mean values for the "adherence to a professional code of conduct and ethics" construct and relevant indicators ranged between 4.9 and 5 . The mode value was 5 , quartile deviation value was 0 , and standard deviation value was less than 1 . These results indicated that all of the indicators in the "patient safety and care," "problem-solving and improvisation," and "adherence to a professional code of conduct and ethics" constructs were important and that the experts had a strong consensus regarding consistency. (4) The mean values for the "professional care" construct and relevant indicators ranged between 4.5 and 5 . The mode value was 5 , quartile deviation values were either 0 or 0.75 , and standard deviation value was less than 1 . These results indicated that this construct and its indicators were important and that the experts had a moderate-to-strong consensus regarding consistency. (5) The mean values for the "resource connection and application" construct and relevant indicators ranged between 4.4 and 4.6 . The mode value was 5 , quartile deviation values were either 0.75 or 1 , and standard deviation value was less than 1 . These results indicated that this construct and its indicators were important, but the experts had a weak consensus regarding consistency. An analysis of the expert opinions regarding the importance and consistency of the various constructs and indicators revealed that expert consensus was achieved. Overall, we developed two core competency dimensions containing 15 indicators across eight constructs for care service departments in vocational high schools.

\section{Establishment and analysis of a professional curriculum for care service education in vocational high schools}

A total of 26 subjects across eight constructs were preliminarily identified for the professional curriculum of care service education in vocational high schools based on a literature review and the focus group outcomes. This preliminary list of subjects and constructs was included in the first round of the Delphi questionnaire survey. After the questionnaires were recovered, the opinions provided by the expert panel were collected and analyzed. A total of 26 subjects were retained. However, one subject was modified in the "creativity and execution" construct. Committee members advised to revise "the application of assistive case design", but they didn't raise obvious suggestions of revision. Therefore, 26 subjects across eight constructs were included in the second round of the Delphi questionnaire survey. The opinions of the expert panel were again collected and analyzed. The 26 subjects and eight constructs were retained; 
however, one subject in the "problem-solving and improvisation" construct was modified. Committee members advised to turn "Case Management" into "An Introduction to Case Management"; that is because the content of case management is too difficult for students at the age of high school, and they just attended the introduction course first. The revised list of subjects and constructs was carried over to the third round of the Delphi questionnaire survey. The experts provided no further opinions in the third round, and the statistical data met all of the pre-established criteria, suggesting that expert consensus was achieved. In this round, all the written expert opinions were acknowledged and corrected. The modifications made in the three rounds of the Delphi questionnaire survey are presented in Table 6. 
Table 6

Questionnaire amendments of the professional curriculum in the three-round Delphi questionnaire survey $(n=10)$.

\begin{tabular}{|c|c|c|c|c|c|c|c|c|c|c|c|c|}
\hline \multirow[t]{2}{*}{ Indicator } & \multicolumn{5}{|c|}{ Amendments in Round 1} & \multicolumn{5}{|c|}{ Amendments in Round 2} & \multicolumn{2}{|c|}{ Amendments in Round } \\
\hline & $\begin{array}{l}\text { Original } \\
\text { items }\end{array}$ & Retained & Amended & Deleted & Added & $\begin{array}{l}\text { Original } \\
\text { items }\end{array}$ & Retained & Amended & Deleted & Added & $\begin{array}{l}\text { Original } \\
\text { items }\end{array}$ & Retained \\
\hline \multicolumn{13}{|l|}{$\begin{array}{l}\text { 1. Interpersonal } \\
\text { communication }\end{array}$} \\
\hline $\begin{array}{l}1.1 \\
\text { Interpersonal } \\
\text { relationship }\end{array}$ & 1 & 1 & 0 & 0 & 0 & 1 & 1 & 0 & 0 & 0 & 1 & 1 \\
\hline \multicolumn{13}{|l|}{$\begin{array}{l}1.2 \text { Interactive } \\
\text { literacy }\end{array}$} \\
\hline \multicolumn{13}{|l|}{ 2. Care } \\
\hline $\begin{array}{l}2.1 \text { Creating } \\
\text { shared value }\end{array}$ & 1 & 1 & 0 & 0 & 0 & 1 & 1 & 0 & 0 & 0 & 1 & 1 \\
\hline \multicolumn{13}{|l|}{$\begin{array}{l}\text { 3. Creativity } \\
\text { and execution }\end{array}$} \\
\hline $\begin{array}{l}\text { 3.1 Proactive } \\
\text { creativity and } \\
\text { program } \\
\text { execution }\end{array}$ & 2 & 1 & 1 & 0 & 0 & 2 & 2 & 0 & 0 & 0 & 2 & 2 \\
\hline \multicolumn{13}{|l|}{$\begin{array}{l}\text { 4. Professional } \\
\text { care }\end{array}$} \\
\hline $\begin{array}{l}\text { 4.1 Basic } \\
\text { caring skills }\end{array}$ & 3 & 3 & 0 & 0 & 0 & 3 & 3 & 0 & 0 & 0 & 3 & 3 \\
\hline $\begin{array}{l}4.2 \text { Practical } \\
\text { caring skills in } \\
\text { real situations }\end{array}$ & 3 & 3 & 0 & 0 & 0 & 3 & 3 & 0 & 0 & 0 & 3 & 3 \\
\hline $\begin{array}{l}4.3 \text { Accuracy of } \\
\text { case } \\
\text { assessment } \\
\text { ability }\end{array}$ & 2 & 2 & 0 & 0 & 0 & 2 & 2 & 0 & 0 & 0 & 2 & 2 \\
\hline \multicolumn{13}{|l|}{$\begin{array}{l}\text { 5. Patient } \\
\text { safety and care }\end{array}$} \\
\hline $\begin{array}{l}5.1 \text { Dealing } \\
\text { with accidents } \\
\text { and } \\
\text { emergencies }\end{array}$ & 2 & 2 & 0 & 0 & 0 & 2 & 2 & 0 & 0 & 0 & 2 & 2 \\
\hline $\begin{array}{l}5.2 \text { Care and } \\
\text { life safety }\end{array}$ & 5 & 5 & 0 & 0 & 0 & 5 & 5 & 0 & 0 & 0 & 5 & 5 \\
\hline \multicolumn{13}{|l|}{$\begin{array}{l}\text { 6. Resource } \\
\text { connection and } \\
\text { application }\end{array}$} \\
\hline $\begin{array}{l}6.1 \text { Being } \\
\text { acquainted and } \\
\text { connected with } \\
\text { care resources }\end{array}$ & 3 & 3 & 0 & 0 & 0 & 3 & 3 & 0 & 0 & 0 & 3 & 3 \\
\hline \multicolumn{13}{|l|}{$\begin{array}{l}6.2 \\
\text { Encouraging } \\
\text { health } \\
\text { promotion } \\
\text { activities }\end{array}$} \\
\hline \multicolumn{13}{|l|}{$\begin{array}{l}\text { 7. Problem- } \\
\text { solving and } \\
\text { improvisation }\end{array}$} \\
\hline $\begin{array}{l}\text { 7.1 Ability to } \\
\text { analyze } \\
\text { problems in } \\
\text { case studies }\end{array}$ & 2 & 2 & 0 & 0 & 0 & 2 & 1 & 1 & 0 & 0 & 2 & 2 \\
\hline $\begin{array}{l}7.2 \text { Ability to } \\
\text { solve problems } \\
\text { in case studies }\end{array}$ & & & & & & & & & & & & \\
\hline
\end{tabular}




\begin{tabular}{|c|c|c|c|c|c|c|c|c|c|c|c|c|}
\hline \multirow[t]{2}{*}{ Indicator } & \multicolumn{5}{|c|}{ Amendments in Round 1} & \multicolumn{5}{|c|}{ Amendments in Round 2} & \multicolumn{2}{|c|}{ Amendments in Round } \\
\hline & $\begin{array}{l}\text { Original } \\
\text { items }\end{array}$ & Retained & Amended & Deleted & Added & $\begin{array}{l}\text { Original } \\
\text { items }\end{array}$ & Retained & Amended & Deleted & Added & $\begin{array}{l}\text { Original } \\
\text { items }\end{array}$ & Retained \\
\hline \multicolumn{13}{|l|}{$\begin{array}{l}\text { 8. Adherence to } \\
\text { a professional } \\
\text { code of } \\
\text { conduct and } \\
\text { ethics }\end{array}$} \\
\hline $\begin{array}{l}8.1 \text { Compliance } \\
\text { with the code } \\
\text { of ethics and } \\
\text { regulations }\end{array}$ & 2 & 2 & 0 & 0 & 0 & 2 & 2 & 0 & 0 & 0 & 2 & 2 \\
\hline $\begin{array}{l}8.2 \\
\text { Understanding } \\
\text { the regulations } \\
\text { related to } \\
\text { caring services }\end{array}$ & & & & & & & & & & & & \\
\hline
\end{tabular}

The opinions provided by the expert panel in the three-round questionnaire survey concerning the overall importance and consistency of the professional curriculum for care service education in vocational high schools are presented in Table 7. (1) In the "interpersonal communication" construct, the mean value was 4.9 , mode value was 5 , quartile deviation value was 0 , and standard deviation value was less than 1 . (2) In the "adherence to a professional code of conduct and ethics" construct, the mean value was 4.9 , mode value was 5 , quartile deviation value was 0 , and standard deviation value was less than 1 . These results indicated that all the subjects in the "interpersonal communication" and "adherence to a professional code of conduct and ethics" constructs were crucial, and the experts had a strong consensus regarding consistency. (3) In the "creativity and execution" construct, the mean values ranged between 4 and 4.4 , mode values were either 4 or 5 , quartile deviation values were either 0 or 1 , and standard deviation value was less than 1 . (4) In the "professional care" construct, the mean values ranged between 4.5 and 5 , mode value was 5 , quartile deviation values were either 0 or 0.75 , and standard deviation value was less than 1. (5) In the "patient safety and care" construct, the mean values ranged between 4.6 and 5 , mode value was 5 , quartile deviation values were either 0 or 0.75 , and standard deviation value was less than 1. (6) In the "resource connection and application" construct, the mean values ranged between 4.4 and 4.8 , mode value was 5 , quartile deviation values were either 0 or 1 , and standard deviation value was less than 1 . These results indicated that all of the subjects in the "creativity and execution," "professional care," "patient safety and care," and "resource connection and application" constructs were vital or essential, and the experts had a strong consensus regarding the consistency of most of the subjects and a weak consensus regarding the consistency of a number of subjects. (7) In the "care" construct, the mean value was 4.7 , mode value was 5 , quartile deviation value was 0.75 , and standard deviation value was less than 1. These results indicated that all of the subjects in this construct were important, but the experts had a weak consensus regarding the consistency. (8) In the "problem-solving and improvisation" construct, the mean values ranged between 4.2 and 4.8 , mode values were either 4 or 5 , quartile deviation values were either 0.25 or 1 , and standard deviation value was less than 1 . These results indicated that all of the subjects in this construct were essential. An analysis of the expert opinions regarding the importance and consistency of the various subjects and constructs for a professional curriculum revealed that expert consensus was achieved. 
Table 7

Overall importance and consistency of the professional curriculum for care service education in vocational high schools $(n=10)$.

\begin{tabular}{|c|c|c|c|c|c|c|}
\hline \multirow{2}{*}{$\begin{array}{l}\text { Indicator } \\
\text { dimension }\end{array}$} & \multirow[t]{2}{*}{ Indicator construct and indicators } & \multirow[t]{2}{*}{ Professional subjects } & \multicolumn{2}{|c|}{ Importance } & \multicolumn{2}{|c|}{ Consistency } \\
\hline & & & Mean & Mode & $\begin{array}{l}\text { Quartile } \\
\text { Deviation }\end{array}$ & $\begin{array}{l}\text { Standard } \\
\text { deviation }\end{array}$ \\
\hline \multirow{8}{*}{$\begin{array}{l}\text { General } \\
\text { competency }\end{array}$} & \multicolumn{6}{|l|}{ 1. Interpersonal communication } \\
\hline & 1.1 Interpersonal relationship & Interpersonal relationships and & 4.9 & 5 & 0 & 0.3 \\
\hline & 1.2 Interactive literacy & & & & & \\
\hline & \multicolumn{6}{|l|}{ 2. Care } \\
\hline & 2.1 Creating shared value & Introduction to human development & 4.7 & 5 & 0.75 & 0.5 \\
\hline & \multicolumn{6}{|l|}{ 3. Creativity and execution } \\
\hline & \multirow{2}{*}{$\begin{array}{l}\text { 3.1 Proactive creativity and program } \\
\text { execution }\end{array}$} & Activity design and conduct & 4.4 & 5 & 1 & 0.8 \\
\hline & & $\begin{array}{l}\text { Design and applications for assistive } \\
\text { program }\end{array}$ & 4.0 & 4 & 0 & 0.6 \\
\hline \multirow{26}{*}{$\begin{array}{l}\text { Professional } \\
\text { competency }\end{array}$} & \multicolumn{6}{|l|}{ 4. Professional care } \\
\hline & \multirow[t]{3}{*}{ 4.1 Basic caring skills } & Introduction to long-term care (I)(II) & 5.0 & 5 & 0 & 0 \\
\hline & & $\begin{array}{l}\text { Practical basic care and experimental } \\
\text { (I)(II) }\end{array}$ & 4.9 & 5 & 0 & 0.3 \\
\hline & & Practicum for fundamental care (I)(II) & 5.0 & 5 & 0 & 0 \\
\hline & \multirow[t]{3}{*}{ 4.2 Practical caring skills in real situations } & $\begin{array}{l}\text { Long-term care facilities and practice } \\
\text { techniques }\end{array}$ & 4.8 & 5 & 0 & 0.6 \\
\hline & & Practicum for community care & 4.7 & 5 & 0 & 0.6 \\
\hline & & Practicum for home care (I)(II) & 4.7 & 5 & 0 & 0.6 \\
\hline & \multirow[t]{2}{*}{ 4.3 Accuracy of case assessment ability } & $\begin{array}{l}\text { Structure and function of human } \\
\text { body (I)(II) }\end{array}$ & 4.7 & 5 & 0 & 0.6 \\
\hline & & $\begin{array}{l}\text { Physical examination and } \\
\text { assessment (I)(II) }\end{array}$ & 4.5 & 5 & 0.75 & 0.8 \\
\hline & \multicolumn{6}{|l|}{ 5. Patient safety and care } \\
\hline & \multirow[t]{2}{*}{ 5.1 Dealing with accidents and emergencies } & $\begin{array}{l}\text { Dealing with accidents and } \\
\text { emergencies }\end{array}$ & 5.0 & 5 & 0 & 0 \\
\hline & & $\begin{array}{l}\text { Home security and accident } \\
\text { prevention }\end{array}$ & 5.0 & 5 & 0 & 0 \\
\hline & \multirow[t]{5}{*}{ 5.2 Care and life safety } & Introduction to nutrition (I)(II) & 4.8 & 5 & 0 & 0.6 \\
\hline & & Disease prevention and chronic care & 4.7 & 5 & 0 & 0.6 \\
\hline & & $\begin{array}{l}\text { Introduction to drug therapy and } \\
\text { medication safety }\end{array}$ & 4.6 & 5 & 0.75 & 0.7 \\
\hline & & $\begin{array}{l}\text { Assistive technology device and } \\
\text { health care }\end{array}$ & 4.7 & 5 & 0 & 0.6 \\
\hline & & $\begin{array}{l}\text { Practicum for assistive technology } \\
\text { device }\end{array}$ & 4.8 & 5 & 0 & 0.6 \\
\hline & \multicolumn{6}{|l|}{ 6. Resource connection and application } \\
\hline & \multirow{3}{*}{$\begin{array}{l}\text { 6.1 Being acquainted and connected with } \\
\text { care resources } \\
6.2 \text { Encouraging health promotion activities }\end{array}$} & Introduction to social welfare & 4.7 & 5 & 0 & 0.6 \\
\hline & & Health promotion practicum & 4.8 & 5 & 0 & 0.4 \\
\hline & & Community health building & 4.4 & 5 & 1 & 0.8 \\
\hline & \multicolumn{6}{|l|}{ 7. Problem-solving and improvisation } \\
\hline & $\begin{array}{l}7.1 \text { Ability to analyze problems in case } \\
\text { studies }\end{array}$ & Introduction to case management & 4.8 & 5 & 0.25 & 0.4 \\
\hline & 7.2 Ability to solve problems in case studies & Practical project (I)(II) & 4.2 & 4 & 1 & 0.7 \\
\hline & \multicolumn{6}{|l|}{$\begin{array}{l}\text { 8. Adherence to a professional code of } \\
\text { conduct and ethics }\end{array}$} \\
\hline & $\begin{array}{l}8.1 \text { Compliance with the code of ethics and } \\
\text { regulations }\end{array}$ & Ethics in long-term care & 4.9 & 5 & 0 & 0.3 \\
\hline
\end{tabular}

Page 16/20 
Overall, we developed 26 subjects for a professional care service curriculum for vocational high schools. One subject centered on "interpersonal communication," one on "care," two on "creativity and execution," eight on "professional care," seven on "patient safety and care," three on "resource connection and application," two on "problem-solving and improvisation," and two on "adherence to a professional code of conduct and ethics." (For complete core competences of innovation and professional curricula, please see attachment 2)

\section{Discussion And Conclusion}

Regarding the core competencies of care services, we identified 15 indicators across eight constructs, namely interpersonal communication, care, creativity and execution, professional care, patient safety and care, resource connection and application, problem-solving and improvisation, and adherence to a professional code of conduct and ethics. With social and economic development, long-term caregivers have gradually formed a consensus that "communication," "assessment," and "direct care" are the key skills required to provide long-term care to older adults. [16, 17, 18, 19] A survey invited 363 nursing home workers and home caregivers with nursing backgrounds to vote on the abilities they deemed necessary for providing long-term care; the participants agreed that interpersonal communication and direct care were essential abilities. [20] The research proposed four crucial abilities of caregivers in nursing homes: (1) interpersonal skills, namely communication, motivation, and conflict management; (2) clinical skills, namely assessing care needs, preparing care plans, performing care tasks, and evaluating care performance; (3) intra-organizational skills, namely formulating plans and contingencies; and (4) management skills, namely following laws and regulations, planning financial budgets, and providing supervision and counseling. [21] And the study proposed three major competencies: (1) interpersonal skills, namely communication, motivation, and conflict management; (2) organizational skills, namely organizational skills, planning service strategies, and utilizing resources; and (3) management skills, namely following laws and regulations, planning financial budgets, and providing supervision and counseling. [22] The conclusions of the preceding two studies are similar to that of the current study. However, when devising the core competencies for long-term care education in high schools, we considered that high school students have not yet developed management skills. Therefore, the development of resource connection and application rather than management abilities seemed more practical at the high school level. The American Geriatrics Society examined the trends of active aging and the establishment of age-friendly environments and recommended that professional undergraduate programs should focus on cultivating the ability to enhance health promotion and safety, assess care needs, formulate care plans and coordinate relevant services, work in a professional team, support caregivers, and utilize resources. These six constructs are similar to those proposed. [23] In summary, caregiver competencies directly influence care quality. Therefore, long-term caregivers must possess specific skills. When working in a team, the ability to work as a team, communicate with team members, comprehend organizational operations, and utilize resources are indispensable competencies. The number of older adults living alone or experiencing depression is rising in Taiwan. We considered these social trends and included "care" to be one of the eight core competencies to cultivate in professionals to address and improve the mental health of older adults.

In terms of the professional curriculum, we identified 26 subjects that constituted 15 core competency indicators and eight constructs for care service departments in vocational high schools. To facilitate caregiver attainment of national accreditation, professional care courses, such as Introduction to LongTerm Care I \& II, Basic Care Practices and Experiments I \& II, and Practical Training on Basic Care I \& II, were listed as mandatory courses. These courses help caregivers attain their caregiver license after graduation and become eligible to work as front-line long-term caregivers. The training programs for cultivating long-term care professionals in Taiwan are offered at three levels, namely Level 1, Level 2, and Level 3. Level 1 programs focus on the fundamentals of longterm care. Subjects include an introduction to long-term care, long-term care requirements, care management, and introduction to and application of care resources. [24] Long-term care involves a wide range of factors. With the demographic structure becoming that of an aging society with a prevalence of chronic illnesses and increased complexities of long-term care, long-term care has evolved from provision of mainstream institutional care (hospitals and nursing homes) to community and home care. The conventional training method focusing on the disease care of older patients no longer meets current demands. $[25,26]$ Therefore, we added three situational care constructs, namely "institutional care," "home care," and "community care," to promote the development of flexible care skills to meet varied situational requirements in students. Furthermore, to help schools develop distinct long-term care characteristics and help students foster creativity, we included a thematic and practical course. Teachers can create thematic booths at high school science fairs and competitions with their students to help students foster the ability to formulate innovative care plans.

The rise in the demand for long-term care resulting from population aging has directed international attention to the need for long-term care. In the past, the core competencies required for providing long-term care could only be cultivated in universities. However, with the predicted exponential growth in the demand for long-term care in the next 10-15 years, the cultivation of long-term caregivers has become a critical concern. In response, the Taiwanese government has promoted the cultivation of caregivers in high school, encouraging vocational high schools to establish care service departments and learning pathways to meet long-term care demands in Taiwan, overturn the stereotype that long-term care is an unspecialized profession, and enhance the willingness of young adults to work in the long-term care industry. These efforts are currently in the preliminary stages. To foster students' professional competencies, we identified the core competencies for long-term care service education and devised a professional curriculum to foster the skills and knowledge among students that are required for successfully meeting the care needs of a rapidly aging society through work in the long-term care industry after graduation.

\section{Declarations}

\section{Acknowledgements}

The authors would like to thank the K-12 Education Administration, Ministry of Education and Research Center for Healthcare Industry Innovation, National Taipei University of Nursing and Health Sciences for their support toward this study. And this manuscript was edited by Wallace Academic Editing. 
Funding

This work was supported by the K-12 Education Administration, Ministry of Education -(Grant number 107G001).

\section{Availability of data and materials}

The datasets used and analyzed in this study are available from the corresponding author upon reasonable request.

\section{Authors' contributions}

JHS wrote the first draft in discussion with $\mathrm{NCH}$ and SFW but the subsequent versions were written in discussion with all authors JMT and LJ L. All authors read and approved the final manuscript.

\section{Competing interests}

The authors declare that they have no competing interests.

\section{Consent to publish}

Not applicable.

\section{Ethics approval and consent to participate}

The research can be exempt from the ethical review of human research according to the regulations of the Review Committee since the case does not take noadults, inmates, aboriginals, pregnant women, physically or mentally challenged, psychosis patients, or people under unreasonable threat or unable to decide based on free will as objects of research, conduct anonymous non-intrusive research in public places, the information gathered is unrecognizable as specific individual, and thus exempt from the ethical review of the Review Committee. (Ministry of Health and Welfare, 2012)

The research also abides by the regulations of journals to apply for the ethical review of the Review Committee (Research Ethics Committee" (REC) of "National Taiwan University" (NTU), Case Number: 202011ES013). In this study, the informed consent was obtained from all the participants On the basis of the aforementioned article, as well as the fact that the research is commissioned by the pubic sectors for professional institutes to conduct national policy related research, the objects of research are found for the purpose of sharing academic professional knowledge and providing recommendations, which do not belong to the domain governed by the Review Committee and thus can be exempt from the ethical review. All methods were performed in accordance with the relevant guidelines and regulations.

\section{References}

1. National Development Council. Analysis of population projections for Taiwan area: 2008 to 2056. https://www.ndc.gov.tw/Content_List.aspx? $\mathrm{n}=84223$ C65B6F94D72 (2018). Accessed 1 May 2018.

2. Ministry of Health and Welfare. Report of the senior citizen condition survey. https://dep.mohw.gov.tw/D0S/lp-1767-113.html (2019). Accessed 1 July 2019.

3. Executive Yuan. Long- term care 1.0 in Taiwan- public welfare construction project. http:// www.cepd.gov.tw/ (2007). Accessed 1 May 2018.

4. Ministry of Health and Welfare. 2025 Health and welfare policy white paper. https://oliviawu.gitbooks.io/2025-whbook/content/ (2016). Accessed 1 May 2018.

5. Liu KS. From the changing long-term care policy to explore the planning direction of the manpower development. Library of Academia Sinica. 2013; 142:304-316.

6. Ministry of Education. Education statistics newsletter. http://stats.moe.gov.tw/files/brief/107\%E5\%AD\%B8\%E5\%B9\%B4\%E5\%A4\%A7\%E5\%B0\%88\%E6\%A0\%A1 \%E9\%99\%A2\%E3\%80\%8C\%E8\%80\%81\%E5\%B9\%B4\%E4\%BA\%BA\%E5\%8F\%8A\%E5\%A4\%B1\%E8\%83 \%BD\%E6\%88\%90\%E4\%BA\%BA\%E7\%85\%A7\%E9\%A1\%A7\%E5\%AD\%B8\%E9\%A1\%9E\%E3\%80\%8D\%E 5\%AD\%B8\%E7\%94\%9F\%E5\%B0\%B1\%E8\%AE\%80\%E6\%A6\%82\%E6\%B3\%81.pdf (2019). Accessed 1 July 2019.

7. Che C. H. (2021). Japanese experience- Establishing a professional system for caregivers. https://www.ankecare.com/2021/23098.

8. Keast, J. (2016). Sector responds to revamped course for care workers. http://www.australianageingagenda.com.au/2016/01/15/37457/

9. Australian Aged Care Quality Agency (2014). New qualifications proposed for aged care, home and community care and disability. Quality Standard, Nov. pp. 3

10. Executive Yuan. Technical and vocational education policy framework. https://ws.moe.edu.tw/001/Upload/3/relfile/6315/52872/d595d36a-1b27-42d3b50f-95c0f4671296.pdf (2017). Accessed 1 May 2018.

11. Directorate-General of Personnel Administration, Executive Yuan. The selection and operation method of professional core competencies for Executive Yuan subordinate agencies. http://www.cpa.gov.tw/cpa2004/plplan/download/PLPS94011101.doc (2005). Accessed 1 May 2018.

12. Hamdi M. Outcome-based education. http://celt.ust.hk/obe/ download/VPAAO_OBEbriefing/ 070313_SENG/ \%20-\%20ABET\%20Criteria.pdf (2007). Accessed 1 May 2018. 
13. Trotter A, Ellison L. Understanding competence and competency. In: Davies B, Ellison L, eds. School Leadership for the 21st Century: A Competency and Knowledge Approach. New York: Routledge; 1997: 36-53.

14. Hsu CS, Huang GH, He YC, Li KY. A Basic Research on the Course Development of Occupational High School: The Core Competencies and Capability Development Mechanism of Occupational High School Students. New Taipei City: National Academy for Educational Research; 2018.

15. Burnette D, Morrow-Howell N, Chen L. Setting priorities for gerontological social work research: a national Delphi study. Gerontologist. 2003;43(6):828838. https://doi.org/10.1093/geront/43.6.828.

16. Chen HT, Li KT. Developing the core competencies of long-term care professionals. J Nurs. 2012;59(6):12-18. https://doi.org/10.6224/JN.59.6.12.

17. Wang HP. Study on learning performance of long-term care in multi-disciplinary program (I) (NO.NSC100-2410-H241-004). https://www.grb.gov.tw/search/planDetail?id=2347973 (2011). Accessed 1 May 2018.

18. Thornlow DK, Auerhahn C, Stanley J. A necessity not a luxury: preparing advanced practice nurses to care for older adults. $J$ Profess Nurs. 2006; 22(2):116-122. https://doi.org/10.1016/j.profnurs.2006.01.015.

19. Mezey M, Quinlan E, Fairchild S, Vezina M. Eriatric competencies for RNs in hospitals. J Nurses Staff Dev. 2006; 22(1):2-10. https://doi.org/10.109/00124645-200601000-00002.

20. Utley-Smith Q. 5 competencies needed by new baccalaureate graduates. Nurs Educ Persp. 2004;25(4):166-170.

21. Harahan MF, Stone RI. Defining core competencies for the professional long-term care workforce: a status report and next steps. http://www.allhealth.org/SCANforum/Mar9Docs/CoreCompetenciesProfessionalReport3209.pdf (2009). Accessed 1 May 2018.

22. Mezey M, Mitty EL, Burger SG, McCallion P. Healthcare professional training: a comparison of geriatric competencies. J Am Geriatr Soc. 2008; 56(9):1724-1729. https://doi.org/10.1111/j.1532-5415.2008.01857x.

23. Damron-Rodriguez J. Developing competence for nurses and social workers. Am J Nurs. 2008; 108(9):40-46. https://doi.org/10.1097/01.NAJ.0000336413.83366.e0.

24. Ministry of Health and Welfare. Long- term care 2.0 in Taiwan. file:///C:/Users/User/Downloads/1051219\%E9\%95\%B7\%E7\%85\%A72.0\%E6\%A0\%B8\%E5\%AE\%9A\%E6\%9C\%AC\%20(1).pdf (2016). Accessed 1 May 2018.

25. Li SD. The development and promotion of long-term care. Taiwan Med J. 2010;53(1):35-41. https://doi.org/10.30044/TMJ.201001.0011.

26. Harahan MF, Stone RI, American Association of Home and Service for the Aging. Defining core competencies for the professional long-term care workforce: a status report and next steps. https://www.leadingage.org/sites/default/files/Defining\%20Core\%20Competencies_FINAL.pdf (2009). Accessed 1 May 2018.

\section{Figures}

\section{From Divergence to Convergence - The 3-Phrase Developmental Process}

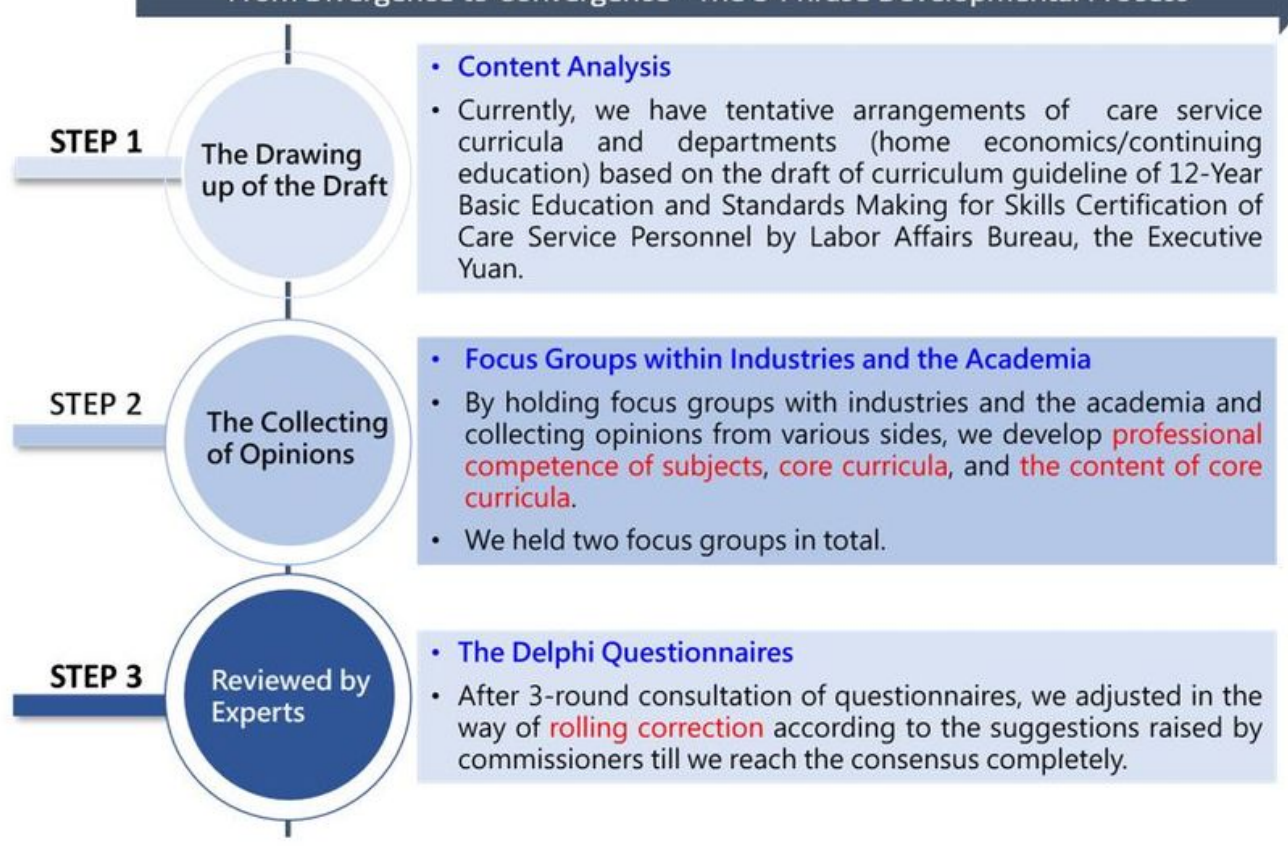

The Drawing up of the Draft:

1. Core Competences- 2 dimensions 7 constructs and 13 indicators

2. Professional Subjects- 25 subjects

Revision after reviewed by experts:

1. Core Competences- 2 dimensions 8 constructs and 13 indicators

2. Professional Subjects- 26 subjects

The Finalizing of the Draft:

1. Core Competences- 2 dimensions 8 constructs and 15 indicators

2. Professional Subjects- 26 subjects

Figure 1

The Graph of Research Procedures 
This is a list of supplementary files associated with this preprint. Click to download.

- Appendix1.docx

Page 20/20 